\title{
A prospective study of fetomaternal outcome in cases of placenta previa
}

\author{
Gunvant K. Kadikar'1, Mayur R. Gandhi², Rakesh R. Kapadia ${ }^{3}$
}

\begin{abstract}
${ }^{1}$ Department of Obstetrics and Gynecology, Government Medical College, Bhavnagar, Gujarat, India ${ }^{2}$ Department of Obstetrics and Gynecology, GMERS Medical College, Himatnagar, Gujarat, India ${ }^{3}$ Consultant Gynaecologist, Bhavnagar, Gujarat, India
\end{abstract}

Received: 03 February 2019

Accepted: 06 March 2019

\section{*Correspondence:}

Dr. Mayur R. Gandhi,

E-mail: maydeep2008@yahoo.com

Copyright: (C) the author(s), publisher and licensee Medip Academy. This is an open-access article distributed under the terms of the Creative Commons Attribution Non-Commercial License, which permits unrestricted non-commercial use, distribution, and reproduction in any medium, provided the original work is properly cited.

\begin{abstract}
Background: The incidence of placenta previa ranges from $0.5-1 \%$ amongst hospital deliveries. Placenta previa is major cause of antepartum haemorrhage and is potentially devastating complication. Obstetric haemorrhage is most common cause for maternal and perinatal morbidity and mortality in India. This study aimed to determine frequency, type of placenta previa, risk factors and adverse fetomaternal outcomes of placenta previa.

Methods: This was a prospective study carried out in Department of Obstetrics and Gynaecology, Government Medical College and Sir-T hospital, Bhavnagar from July 2007 to July 2009 to analyze fetomaternal outcome in cases of placenta previa. All patients of placenta previa with gestational age $>28$ weeks up to full term were included in the study. All cases were confirmed by Ultrasound examination. All cases were carefully analyzed to find out the incidence, type of placenta previa, its clinical presentation and its outcome in relation to mode of delivery, birth weight, maternal and perinatal morbidity.

Results: There was total 50 cases of placenta previa out of 5636 deliveries. The prevalence of placenta previa was $0.88 \%$ and was more commonly present among multiparous women (82\%). Most common type was type IV placenta previa in $23(46 \%)$ cases followed by type III in $11(22 \%)$ cases. Out of 50 cases, $06(12 \%)$ cases had atonic PPH and $02(04 \%)$ cases underwent peripartum hysterectomy. Most common predisposing factors were age $>35$ years $(04 \%)$, multiparity (50\%), previous cesarean section (16\%) and previous history of abortion (12\%). All cases of perinatal mortality were between 28 to 30 weeks weighing between $1-1.5 \mathrm{~kg}$. There was no maternal mortality in this study.

Conclusions: Managing a case of placenta previa during pregnancy poses a great challenge to every obstetrician in present day obstetrics due to its increased risk of maternal and perinatal complications.
\end{abstract}

Keywords: Antepartum haemorrhage, Bleeding per vagina, Low lying, Placenta previa

\section{INTRODUCTION}

Vaginal bleeding at any stage of pregnancy is alarming event. Obstetrics is bloody business. ${ }^{1}$ Even though institutional delivery, availability of blood dramatically reduced maternal mortality rate, death from haemorrhage still remains a leading cause of maternal mortality. Placenta previa literally means afterbirth first. In placenta previa, the placenta is located over or very near the internal os. The incidence of placenta previa has been recently estimated to be $0.5-1 \%$ of all pregnancies and this increase correlates to the elevated cesarean section rate. ${ }^{2}$ Placenta previa is a major cause of maternal morbidity and mortality because of the associated massive antepartum and intrapartum haemorrhage. ${ }^{3}$ Risk factors are old age, multiparity, previous caesarean 
section delivery, abortion, smoking, cocaine and male fetus. ${ }^{4}$ In placenta previa risk of postpartum haemorrhage is substantial which increases maternal morbidity and mortality.

Risk factors for massive haemorrhage and transfusion are old age, abortion, previous cesarean section, uterine myoma, increased BMI, increased neonatal weight and complete previa. ${ }^{5}$

Placenta previa is also associated with abnormal placentation and preterm delivery. History and number of previous cesarean delivery is important to have placenta previa and abnormal placentation in subsequent pregnancies. $^{6}$

The need for the study is because Placenta previa is one of the major causes for antepartum haemorrhage and is responsible for increased maternal and perinatal morbidity and mortality. This study is conducted to know the frequency, type of placenta previa, risk factors, various clinical presentations and fetomaternal outcome in cases of placenta previa in a teaching hospital.

\section{METHODS}

This is a prospective study carried out in Department of Obstetrics and Gynaecology, Government Medical College and Sir-T hospital, Bhavnagar from July 2007 to July 2009 to analyses fetomaternal outcome in case of placenta previa. All patients of placenta previa with gestational age $>28$ weeks up to full term were included in the study. All cases were confirmed by Ultrasound. All cases were carefully analyzed to find out the incidence, type of placenta previa, its clinical presentation and its outcome in relation to mode of delivery, birth weight, maternal and perinatal morbidity.

\section{Inclusion criteria}

- All patients admitted with placenta previa > 28 weeks up to the full-term pregnancy.

- Ultrasound confirmed diagnosis of placenta previa was done.

\section{Exclusion criteria}

- Pregnancy < 28 weeks gestation.

- Bleeding due to trauma.

- Bleeding due to abruption placenta.

- Mixed variety.

At the time of admission all patients were examined in detail.

\section{RESULTS}

In present study 50 cases of placenta previa were found out of total 5636 deliveries. During the study period incidence of placenta previa is $0.88 \%$ or $1: 112$ as our hospital is a tertiary center and because of lack of facilities at rural area (Table 1).

Table 1: Incidence of placenta previa.

\begin{tabular}{|l|l|l|l|l|}
\hline Period & $\begin{array}{l}\text { Total } \\
\text { no. of } \\
\text { delivery }\end{array}$ & $\begin{array}{l}\text { Cases of } \\
\text { placenta }\end{array}$ & $\%$ & Ratio \\
\hline $\begin{array}{l}\text { July 2007- } \\
\text { July 2008 }\end{array}$ & 2798 & 20 & 0.72 & $1: 139$ \\
\hline $\begin{array}{l}\text { August 2008- } \\
\text { August 2009 }\end{array}$ & 2838 & 30 & 1.05 & $1: 94$ \\
\hline Total & 5636 & 50 & 0.88 & $1: 112$ \\
\hline
\end{tabular}

In present study, 41 cases (82\%) were multiparous followed by 09 cases $(18 \%)$ were primipara. It shows that multiparty increases the risk of placenta previa (Table 2).

Table 2: Incidence of placenta previa in respect to parity.

\begin{tabular}{|l|l|l|}
\hline Parity & \multicolumn{2}{c}{ Study group $\mathbf{N = 5 0}$} \\
\hline Primipara & 09 & $\%$ \\
\hline Para 2 & 18 & 18 \\
\hline Para 3 & 13 & 36 \\
\hline Para $>$ 4 & 10 & 26 \\
\hline Total & 50 & 20 \\
\hline Mean parity $=2.58$ & 100 \\
\hline
\end{tabular}

Out of 50 cases, 35 cases $(70 \%)$ were between $28-36$ weeks gestation whereas 15 cases $(30 \%)$ were between 37-40 weeks of gestation. $70 \%$ cases were preterm in present study and prematurity is a major factor for increased perinatal morbidity and mortality in cases of placenta previa (Table 3).

Table 3: Gestational age at the time of admission.

\begin{tabular}{|l|l|l|}
\hline \multirow{2}{*}{ Gestational age (weeks) } & \multicolumn{2}{|c|}{ Study group N=50 } \\
\hline $28-31$ & No. & \% \\
\hline $32-36$ & 13 & 26 \\
\hline $37-40$ & 22 & 44 \\
\hline Total & 15 & 30 \\
\hline
\end{tabular}

Table 4: Severity of bleeding.

\begin{tabular}{|l|l|l|}
\hline \multirow{2}{*}{ Amount } & Study group & $\mathbf{N}=50$ \\
\hline No & No. & $\%$ \\
\hline Mild & 01 & 02 \\
\hline Moderate & 18 & 36 \\
\hline Severe & 15 & 30 \\
\hline Total & 16 & 32 \\
\hline
\end{tabular}

In present study, 16 cases (32\%) presented with severe bleeding per vagina whereas 33 cases $(66 \%)$ presented with mild to moderate bleeding per vagina which 
increases both fetomaternal morbidity and mortality (Table 4).

Out of 50 cases, 25 cases (50\%) were multiparous followed by 08 cases $(16 \%)$ with previous cesarean section and 06 cases (12\%) with previous history of abortion. This suggests that both multiparity and advanced age are aetiological factors in placenta previa. Probability of placenta previa increases 4-5 times in patients with previous cesarean section. Endometrial damage in previous history of abortion is a predisposing factor for placenta previa (Table 5).

Table 5: Conditions associated with placenta previa.

\begin{tabular}{|l|l|l|}
\hline \multirow{2}{*}{ Conditions } & \multicolumn{2}{c|}{ Study group $\mathbf{N}=50$} \\
\hline Age >50 years & No. & $\%$ \\
\hline Multiparity & 02 & 04 \\
\hline Previous LSCS & 25 & 50 \\
\hline Previous H/O abortion & 08 & 16 \\
\hline Previous H/O placenta previa & 06 & 12 \\
\hline Twins gestation & 00 & 00 \\
\hline & 00 & 00 \\
\hline
\end{tabular}

Most common presentation was cephalic accounting for 38 cases $(76 \%)$, followed by 07 cases $(14 \%)$ of breech presentation and 05 cases $(10 \%)$ of transverse lie. It shows that malpresentation is more common in cases of placenta previa (Table 6).

Table 6: Presentation in placenta previa.

\begin{tabular}{|l|l|l|}
\hline & Study Group N=50 \\
\hline Presentation & No. & \% \\
\hline Cephalic & 38 & 76 \\
\hline Breech & 07 & 14 \\
\hline Transverse & 05 & 10 \\
\hline Total & 50 & 100 \\
\hline
\end{tabular}

Out of 50 cases, 38 cases $(76 \%)$ had major degree placenta previa whereas 12 cases $(24 \%)$ had minor degree of placenta previa (Table 7).

Table 7: Degree of placenta praevia.

\begin{tabular}{|l|l|l|}
\hline \multirow{2}{*}{ Degree } & Study group & N=50 \\
\hline I & No. & \% \\
\hline II Anterior & 05 & 10 \\
\hline II Posterior & 07 & 14 \\
\hline III & 04 & 08 \\
\hline IV & 11 & 22 \\
\hline Total & 23 & 46 \\
\hline
\end{tabular}

45 cases (90\%) were delivered by cesarean section whereas 05 cases $(10 \%)$ were delivered by vaginal route. This shows that there is high incidence of cesarean section in cases of placenta previa (Table 8). Out of 38 cases of major degree placenta previa, 30 cases were transfused more than 01 unit of blood whereas out of 12 cases of minor degree of placenta previa, 06 cases required more than 01 unit of blood.

Table 8: Mode of delivery.

\begin{tabular}{|l|l|l|l|l|}
\hline $\begin{array}{l}\text { Mode of } \\
\text { delivery }\end{array}$ & \multicolumn{2}{|l}{$\begin{array}{l}\text { Study group } \\
\text { N=50 }\end{array}$} & \multicolumn{2}{l}{$\begin{array}{l}\text { Other than placenta } \\
\text { previa }\end{array}$} \\
\hline No. & $\mathbf{\%}$ & No. & $\%$ \\
\hline Vaginal & 45 & 90 & 1090 & 19.51 \\
\hline Total & 05 & 10 & 4496 & 80.49 \\
\hline
\end{tabular}

Maximun 06 units of blood were given to a patient of grade IV placenta previa, who was deliverd by cesarean section developed atonic PPH and required obstetric hysterectomy (Table 9).

Table 9: Blood transfusion and type of placenta previa.

\begin{tabular}{|l|l|l|l|l|}
\hline Degree & $\begin{array}{l}\text { No. of } \\
\text { cases }\end{array}$ & \multicolumn{1}{|c|}{ No. of units of blood } \\
\hline I & 05 & 03 & 00 & 02 \\
\hline II Anterior & 07 & 01 & 02 & 04 \\
\hline II Posterior & 04 & 00 & 03 & 01 \\
\hline III & 11 & 00 & 02 & 09 \\
\hline IV & 23 & 00 & 03 & 20 \\
\hline
\end{tabular}

06 cases (12\%) had PPH, 02 cases (04\%) required obstetric hysterectomy due to intractable haemorrhage (Table 10).

Table 10: Maternal morbidity.

\begin{tabular}{|l|l|l|}
\hline \multirow{2}{*}{ Morbidity } & \multicolumn{2}{l|}{ Study group N=50 } \\
\hline Post-partum haemorrhage & 06 & $\mathbf{\%}$ \\
\hline Obstetric hysterectomy & 02 & 04 \\
\hline Wound gap & 02 & 04 \\
\hline Post op fever & 01 & 02 \\
\hline DIC due to PPH & 01 & 02 \\
\hline
\end{tabular}

35 cases $(70 \%)$ had live birth followed by 11 cases $(22 \%)$ had stillbirth and 04 cases $(08 \%)$ had neonatal death. Out of $30 \%$, total $8 \%$ of neonatal deaths were due to prematurity, birth asphyxia and septicemia (Table 11).

Table 11: Perinatal outcome.

\begin{tabular}{|l|l|l|}
\hline Perinatal outcome & No. of cases & $\%$ \\
\hline Live birth & 35 & 70 \\
\hline Still birth & 11 & 22 \\
\hline Neonatal death & 04 & 08 \\
\hline
\end{tabular}

Table 12 shows that perinatal mortality was high in study conducted by Das B. ${ }^{7}$ Table 13 shows that 27 (54\%) babies were delivered before 37 weeks and out of them $14(28 \%)$ were still birth and neonatal death which was 
mostly because of prematurity, whereas $23(46 \%)$ babies were delivered after 37 weeks and out of them only 1 (2\%) was stillbirth (Table 13).

Table 12: Comparison of perinatal mortality.

\begin{tabular}{|c|c|c|}
\hline Author & Year & $\%$ \\
\hline Das $B^{7}$ & $1941-1970$ & 34.3 \\
\hline Present study & 2007-2009 & 30 \\
\hline
\end{tabular}

Table 13: Perinatal outcome in relation to maturity.

\begin{tabular}{|l|l|l|l|l|l|l|}
\hline $\begin{array}{l}\text { Maturity } \\
\text { (weeks) }\end{array}$ & $\begin{array}{l}\text { Live } \\
\text { birth } \\
(\mathbf{N = 3 9 )}\end{array}$ & $\begin{array}{l}\text { Still birth } \\
\text { and } \\
\text { neonatal } \\
\text { death } \\
(\mathbf{N = 1 5})\end{array}$ & $\begin{array}{l}\text { Total } \\
(\mathbf{N}=50)\end{array}$ \\
\hline & No. & $\%$ & No. & \% & No. & $\%$ \\
\hline <37 Weeks & 17 & 34 & 14 & 28 & 27 & 54 \\
\hline$>37$ Weeks & 22 & 44 & 01 & 02 & 23 & 46 \\
\hline Total & 39 & 78 & 15 & 30 & 50 & 100 \\
\hline
\end{tabular}

Table 14 shows that perinatal outcome was better in cases of cesarean delivery ( $73.33 \%$ of live birth).

Table 14: Perinatal outcome and mode of delivery.

\begin{tabular}{|l|l|l|l|l|l|}
\hline $\begin{array}{l}\text { Mode } \\
\text { of } \\
\text { delivery }\end{array}$ & $\begin{array}{l}\text { No. of } \\
\text { babies } \\
\text { born }\end{array}$ & $\begin{array}{l}\text { Still } \\
\text { birth }\end{array}$ & $\begin{array}{l}\text { Neonatal } \\
\text { Death }\end{array}$ & $\begin{array}{l}\text { Total } \\
\text { live } \\
\text { birth }\end{array}$ & $\begin{array}{l}\% \text { of } \\
\text { live } \\
\text { birth }\end{array}$ \\
\hline LSCS & 45 & 08 & 04 & 33 & 73.33 \\
\hline Vaginal & 05 & 03 & 00 & 02 & 40 \\
\hline Total & 50 & 11 & 04 & 35 & \\
\hline
\end{tabular}

\section{DISCUSSION}

The present study was carried out to know the incidence of placenta previa, to evaluate the various types of placenta previa and its clinical presentation and fetomaternal outcome in patients admitted during July 2007 to July 2009 in teaching hospital.

The prevalence of placenta previa was 50 cases among 5636 deliveries accounting for $0.88 \%$ which was similar to study by Das B $(0.72 \%){ }^{7}$

In present study, mean age of patient was 26 years which was similar to the study by Richard Silver. ${ }^{8}$ Placenta previa was more commonly present among multiparous women $(82 \%)$ which was similar to the study conducted by Faiz. ${ }^{4}$

In present study $70 \%$ patients were admitted before 37 weeks of gestation which is in agreement with study conducted by Bhaskar Rao. ${ }^{9}$

In present study abnormal presentations were present in $76 \%$ of patients which was similar to the study conducted by Bhaskar Rao. ${ }^{9}$ Major degree placenta previa was present in $76 \%$ of patients in present study which was similar to the study conducted by Bhaskar Rao (69.5\%). ${ }^{9}$

In present study $90 \%$ of patients were delivered by cesarean section which was $68.2 \%$ in study conducted by Bhaskar Rao as most of the patients in present study belongs to major degree placenta previa. ${ }^{9}$

Perinatal mortality was present in $30 \%$ of present study which was similar to the study conducted by Bhaskar Rao $(34.3 \%){ }^{9}$

Out of 50 cases, 06 (12\%) cases had PPH which was similar to the study by Bhatt AP $(15 \%) .{ }^{10}$

\section{CONCLUSION}

Managing a case of placenta previa poses a great challenge to every obstetrician in present day obstetrics due to its increased risk of maternal and perinatal complications. Placenta previa has multifactorial etiology.

Regular antenatal check-ups with antenatal diagnosis of placenta previa, correction of anemia, timely referral and management at tertiary level equipped with blood and blood products, availability of senior obstetrician, NICU facility will definitely help in reducing the maternal and perinatal complications. Obstetric ICU/HDU facility will further help in better management of such cases.

\section{Funding: No funding sources \\ Conflict of interest: None declared}

Ethical approval: The study was approved by the Institutional Ethics Committee

\section{REFERENCES}

1. Williams obstetrics study guide. Hoffman, Barbara L; Horsager, Robyn; Roberts, Scott, (Professor of Obstetrics and Gynecology). 24 ${ }^{\text {th }}$ edition. New York: McGraw-Hill Education, 2014.

2. Crane JM, Van den Hof MC, Dodds L, Armson BA, Liston R. Maternal complications with placenta previa. Am J Perinatol. 2000;17(2):101-5.

3. Sekiguchi A, Nakai A, Kawabata I, Hayashi M, Takeshita T. Type and location of placenta previa affect preterm delivery risk related to antepartum hemorrhage. Int J Med Sci. 2013; 0(12):1683-8.

4. Faiz AS, Ananth CV. Etiology and risk factors for placenta previa: An overview and metaanalysis of observational studies. J Maternal Fetal Neonatal Med.2003;13(3):175-90.

5. Jang DG, We JS, Shin JU, Choi YJ, Ko HS. Maternal outcomes according to placental position in placenta previa. Int J Med Sci. 2011; 8(5):439-44.

6. Nankali A, Keshavarzi F, Shajari A, Daeichin S. Frequency of placenta previa and maternal morbidity associated with previous cesarean delivery. Open J Obstet Gynecol. 2014;4(14):903. 
7. Das B. Antepartum haemorrhage in three decades. J Obstet Gynecol India. 1975;25:636-7.

8. Silver R, Depp R, Sabbagha RE, Dooley SL, Socol ML, Tamura RK. Placenta previa: aggressive expectant management. Am J Obstet Gynecol. 1984;150(1):15-22.

9. Bhaskar RK, Manorama S, Maternal prognosis in placenta previa. J Obstet Gynecol India. 1975;25:642-46.
10. Bhatt AD, Meena A, Desai MR, Maternal and perinatal outcome in cases of placenta previa. Int $\mathrm{J}$ of Sci and Res (IJSR). 2014;3(1):299-301.

Cite this article as: Kadikar GK, Gandhi MR, Kapadia RR. A prospective study of fetomaternal outcome in cases of placenta previa. Int J Reprod Contracept Obstet Gynecol 2019;8:1403-7. 